\title{
An extension of the floodpulse concept (FPC) for lakes
}

\author{
Karl M. Wantzen · Wolfgang J. Junk • \\ Karl-Otto Rothhaupt
}

(C) Springer Science+Business Media B.V. 2008

\begin{abstract}
This paper delivers a conceptual framework for the ecological functioning and biodiversity patterns of lakes that is based on the floodpulse concept (FPC). The specific characteristics of rivers and lakes considering water-level fluctuations are compared, with respect to catchment linkages, temporal patterns, and hydraulic forces of flooding and drawdown. The influences of floodpulses on element cycles, biodiversity, and adaptations of lake biota are analyzed, and the importance of multi-annual flooding cycles is highlighted. The degree by which these water-level fluctuations influence lake ecosystems strongly depends on lake morphology, where shallow lakes or those with large shallow margins are the most sensitive. Although floodpulses play a major role for ecosystem services such as lake management and climate change mitigation schemes, this issue is only scarcely dealt with. Tenets of the extended FPC for lakes are formulated in order to overcome this problem.
\end{abstract}

Guest editors: K. M. Wantzen, K.-O. Rothhaupt, M. Mörtl, M. Cantonati, L. G.-Tóth \& P. Fischer

Ecological Effects of Water-Level Fluctuations in Lakes

K. M. Wantzen $(\bowtie) \cdot$ K.-O. Rothhaupt

Limnologisches Institut der Universität Konstanz,

78457 Konstanz, Germany

e-mail: matthias.wantzen@uni-konstanz.de

\section{W. J. Junk}

Max-Planck-Institut für Limnologie, Max-Planck-Institut für Limnologie, AG Tropenökologie, 24302 Plon,

Germany
Keywords Flood pulse · Water-level fluctuations · Ecological concept $\cdot$ Lake $\cdot$ Ecosystem theory

\section{Introduction}

In rivers, the patterns of water-level fluctuations (the floodpulse) have been recognized both for ecological and biodiversity concepts (Junk et al., 1989; Tockner et al., 2000; Junk \& Wantzen, 2004) and for management and restoration schemes (Sparks et al., 1998; Schiemer et al., 1999). In lakes, however, these pulses have yet to receive attention ( Keddy \& Fraser, 2000; Coops et al., 2003; Mooij et al., 2005). However, this lack of knowledge stands diametrically opposed to recent developments. Both climate and human impacts tend to impair water-level fluctuations in lakes. Current climate models affirm that the frequency of irregular climate events (extreme rainfall, extended drought) is increasing, while predictable hydrological events, such as long lasting springfloods caused by snowmelt in the mid-elevation mountains of the temperate zones are decreasing (IPCC, 2001). Moreover, many direct man-made manipulations of lake levels change timing, frequency and fluctuations of water levels in lakes. For example, Scandinavian lakes dammed for hydropower suffer untimely drawdown in the winter caused by large energy demands. Many lakes of the world, such as Lake Kinnereth (Israel), witness a continuous drawdown due to drinking water demand. 
These current trends cause an additional need to formulate an overarching concept for the effects of water-level fluctuations such as floodpulses in lakes. This paper summarizes the current studied effects of water-level fluctuations in lakes, compares them with similar processes in rivers, and formulates an extension of the floodpulse concept (Junk et al., 1989; Junk \& Wantzen, 2004) for lakes.

There are many open questions about effects of water-level fluctuations in lakes:

- What are the differences in lake flooding compared with river flooding?

- Is it possible to define "flooding-types" of lakes according to their climatic and morphological conditions?

- How is the biota of the lake littoral adapted to the influences of floodpulses?

- How do human activities influence floodpulses in lakes and how can they be managed better?

This paper attempts to answer these questions based on four case studies which delineate the extremes in climatic gradient (temperate to tropical) and morphological gradient (deep to shallow).

\section{Case study lakes}

Lake Constance (Bodensee): temperate-deep

Today, only few lakes such as Lake Constance are left unregulated in Central Europe (Fig. 1). Lake Constance consists of subbasins, the deep "Obersee" $\left(473 \mathrm{~km}^{2}\right.$, maximum depth $254 \mathrm{~m}$ ) with steeply sloped banks, and the shallow "Untersee" $\left(63 \mathrm{~km}^{2}\right.$, maximum depth $20 \mathrm{~m}$ ). The lake has been subject to intensive studies (e.g., Bäuerle \& Gaedke, 1999; Straile et al., 2007, and several papers in this issue). Its annual water-level fluctuations average $1.3 \mathrm{~m}$. The littoral zone is affected by strong seasonal dynamics in water level and waterlevel-driven environmental factors caused by storage of precipitation in the alpine parts of the catchment during winter, and a superposition of rainfall and snowmelt in early summer (Fig. 2). High-water phases lead to a dislocation of gravel and the formation of gravel bars which represent new habitats. Water levels drop from summer to winter, and large littoral zones become exposed. During the heart of winter (December to March), the superficial sediments in the dry-fallen zone

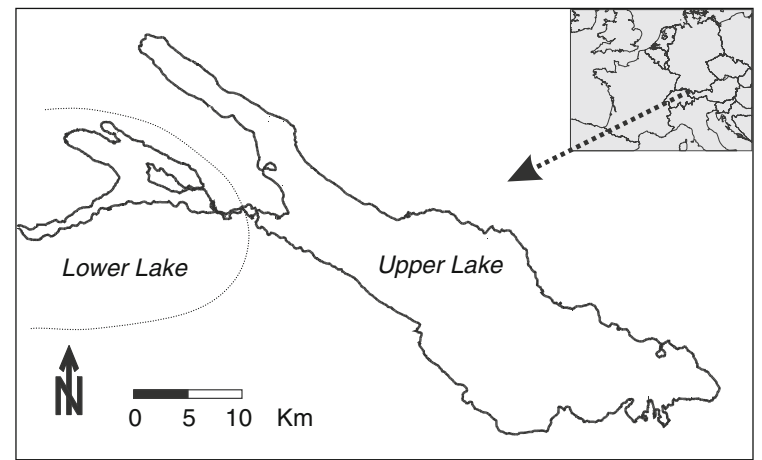

Fig. 1 Map of Lake Constance. Graph provided by Martin Mörtl
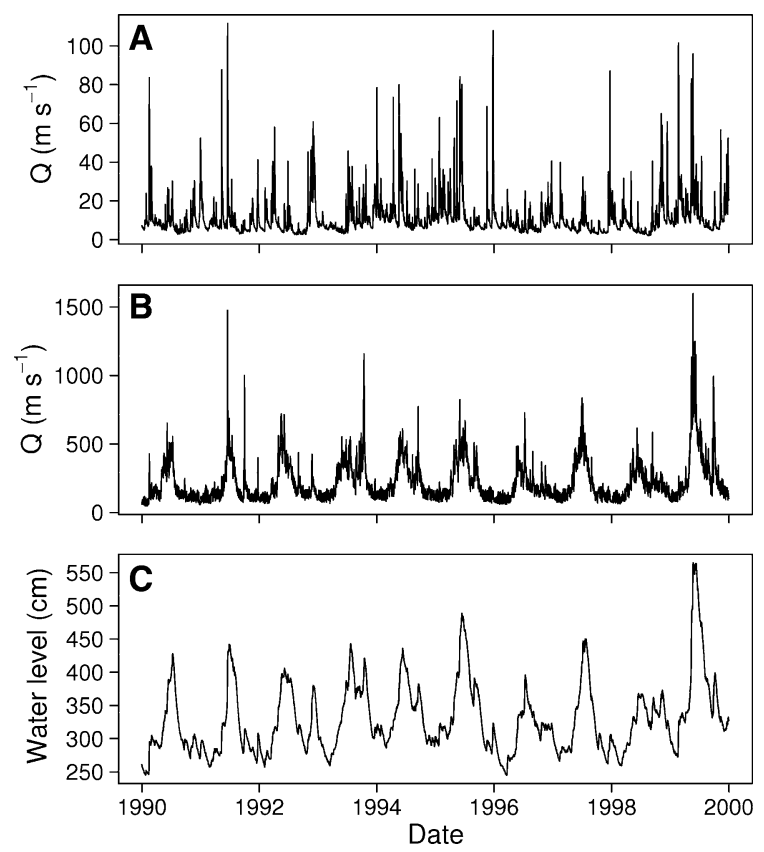

Fig. 2 Discharge of tributaries to Lake Constance (A) Schussen (catchment size $791 \mathrm{~km}^{2}$ ) at Gerbertshaus, (B) Alpine Rhine (catchment size $6,119 \mathrm{~km}^{2}$ ), and (C) of Lake Constance (catchment size of the Upper Lake 10,410 $\mathrm{km}^{2}$ ) at Konstanz harbor. Note the "smoothening" of the discharge/ gage patterns with increasing catchment size. Daily data by LUBW Baden-Württemberg and BAFU, Switzerland. Graph provided by Karsten Rinke

often freeze, while the lower-lying substrate layerswhich are often oxygen-poor to anoxic-remain unfrozen. Subsurfaces in smaller streams remain in this zone and represent ice-free refuges. From March through mid-July, water levels rise and the epilittoral zone becomes flooded. There is a large seasonal variation in this type of flooding. In 1999, the water level (measured at the Port of Konstanz) was $560 \mathrm{~cm}$, 
exceeding the long-term average maximum of $420 \mathrm{~cm}$ by far, and flooding large areas (Schmieder et al., 2004).

Neusiedler See: temperate-shallow

Neusiedler See (Lake Fertõ, Fig. 3) is a steppe or plain lake, situated on the Hungarian-Austrian border, with a surface area of $309 \mathrm{~km}^{2}$. It is an extremely shallow lake with an average depth of $1.1 \mathrm{~m}$. Outside of two small permanent tributaries, the lake mainly receives influxes of groundwater and direct rainfall. Neusiedler See's outflow is regulated (Löffler, 1997; Dinka et al., 2004). Seasonal water-level fluctuations in Neusiedler See show a relatively regular pattern with annual amplitude of about $0.4 \mathrm{~m}$ (Fig. 4). These fluctuations are governed by the seasonal interplay of
Fig. 3 Map of Lake Neusiedler See (from Dinka et al., 2004)

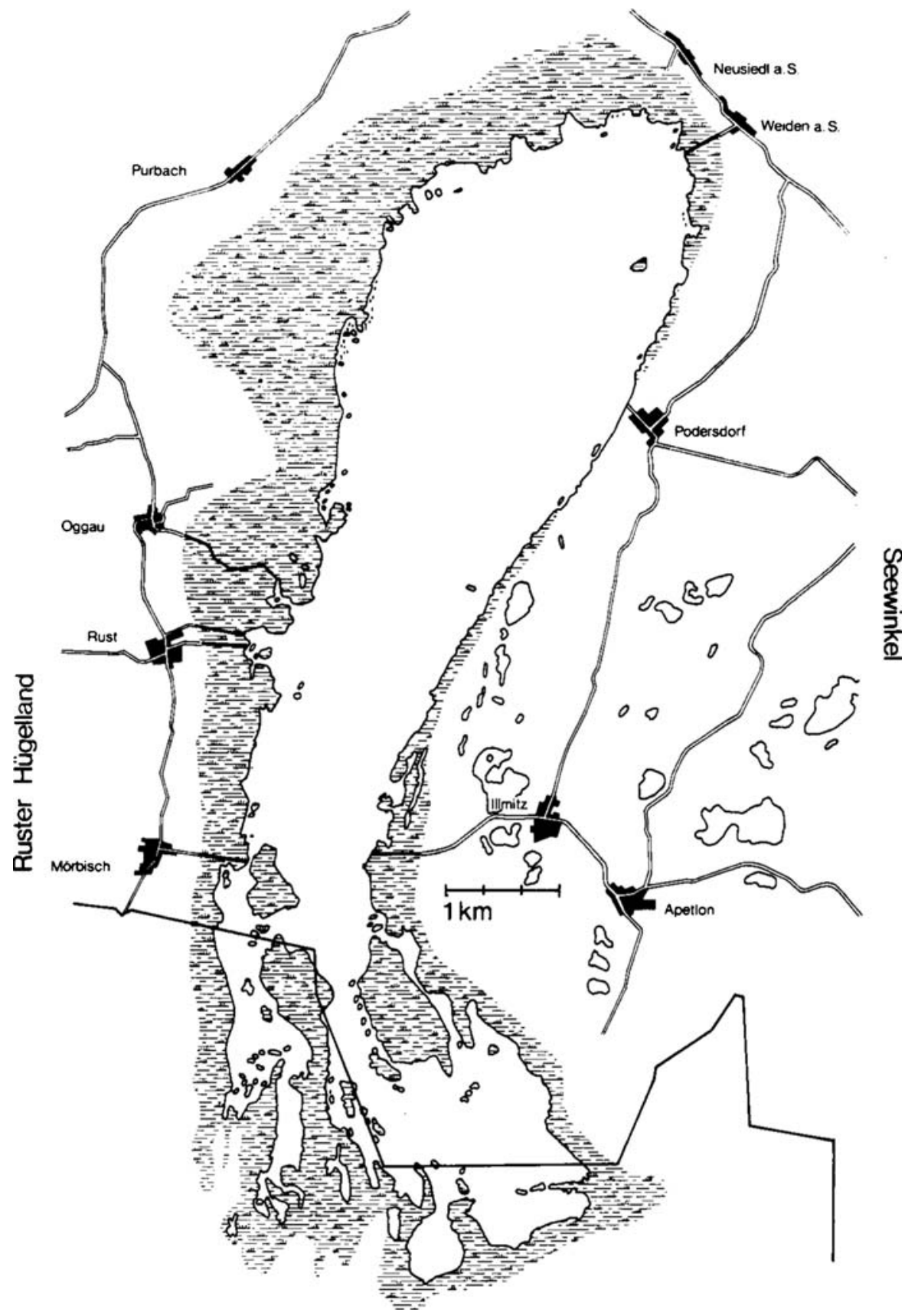


Fig. 4 Hydrograph of Lake Neusiedler See 1991-2003 (from Dinka et al., 2004)

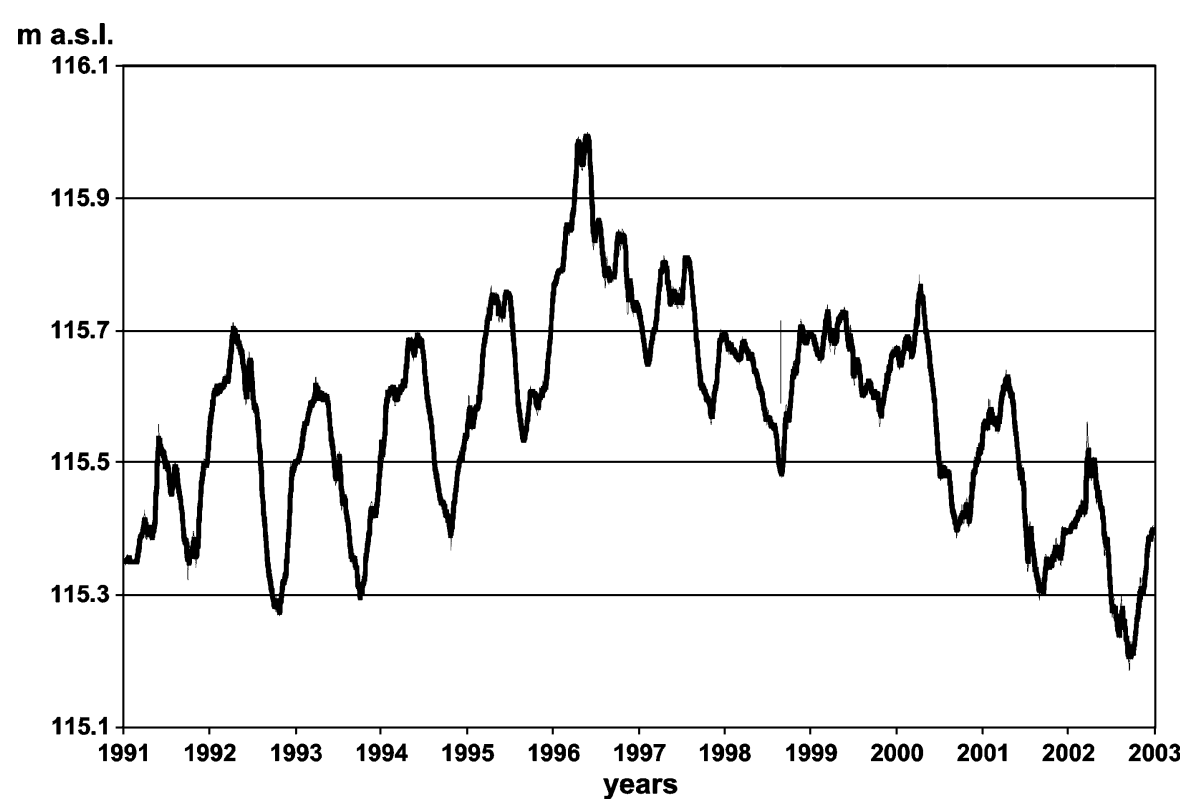

evaporation and inflow (Dinka et al., 2004). Evaporation from the lake surface is low early in the year, when the air is moist and the lake water is relatively cold. Hence, water levels rise in late winter and spring. Maximum water levels occur in late spring to early summer (May/June). Evaporation from the lake surface and evapotranspiration from the extensive reed belts are highest in the second half of the vegetation period. Consequently, the water level decreases during summer and autumn and reaches its minimum in late autumn (October/November). The overall seasonal patterns of water-level fluctuations in Neusiedler See is comparable to the pattern observed in Lake Constance; however, the seasonal events occur about two months earlier in Neusiedler See.

Superimposing the typical seasonal patterns the long-term fluctuations in the water level of Neusiedler See are important drivers of ecological processes (Löffler, 1997). Consecutive wet and cold years cause an increase in water levels, whereas a sequence of warm and dry years can cause a decrease. When the water levels are high, reed stands and open water areas are connected. However, at low water levels, the water surface is discontinuous and some areas with water become disconnected. Moreover, the water levels have a great influence on the chemical composition of the lake water. Conductivity and ion concentrations increase in low water years (Dinka et al., 2004).

\section{Lake Titicaca: tropical-deep}

Lake Titicaca is a high-mountain (3809 m altitude) endorheic lake in the Andes of Bolivia and Peru (Fig. 5, Roche et al., 1992). Its climate is cold and semiarid with mean annual temperatures of $8^{\circ} \mathrm{C}$ and precipitation between $790 \mathrm{~mm}$ and $950 \mathrm{~mm}$ a year. The surface water temperature ranges from $10^{\circ} \mathrm{C}$ to $16^{\circ} \mathrm{C}$. The lake catchment covers an area of $49,010 \mathrm{~km}^{2}$. The lake itself has an approximate size of $8,490 \mathrm{~km}^{2}$. The mean depth of the main basin is more than $100 \mathrm{~m}$, its maximum depth $280 \mathrm{~m}$, the mean volume $930 \times 10^{9} \mathrm{~m}^{3}$. It has pronounced annual and multi-annual water-level fluctuations (Fig. 6). The annual minimum occurs in December, just before the start of the rains. The increase of water occurs more quickly, as all inputs are concentrated during a 5-month period, whereas losses due to evaporation are spread more evenly over the year. From a time series of daily records from 1914 to 1989, Roche et al. (1992) identified an annual range of $0.4-1.8 \mathrm{~m}$ and a total interannual range of $6.27 \mathrm{~m}$. The lake shows pronounced phases of higher and lower water levels. Fluctuations in water levels are decisive in determining the separation and re-establishment of communication (flow) between the two subbasins. They have a direct impact on the zonation of the aquatic macrophytes in the lake. A palynological reproduction of the lake environments revealed 
Fig. 5 Map of Lake Titicaca (modified after Villwock, 1993)

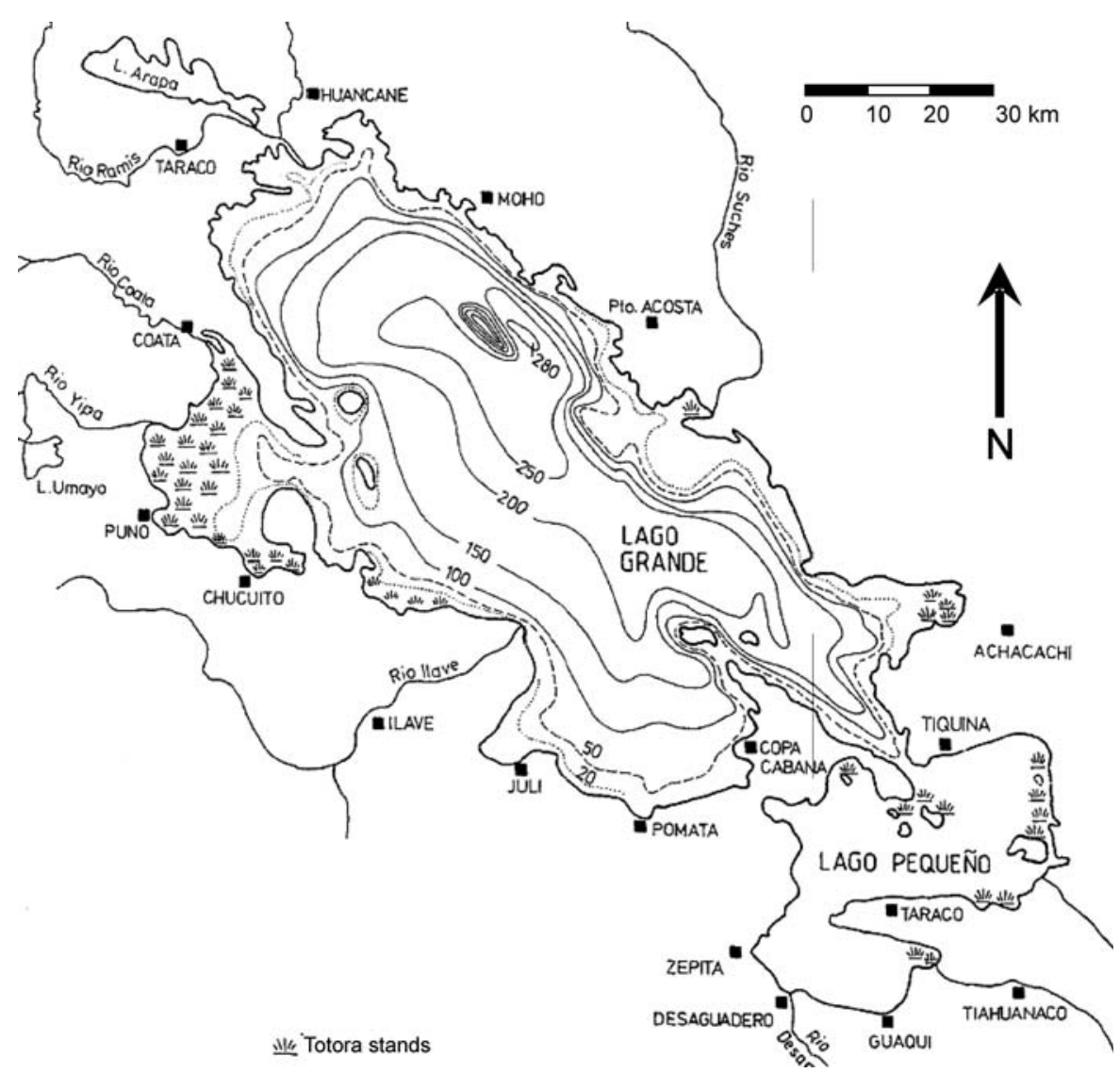

Lake Chad: subtropical-shallow

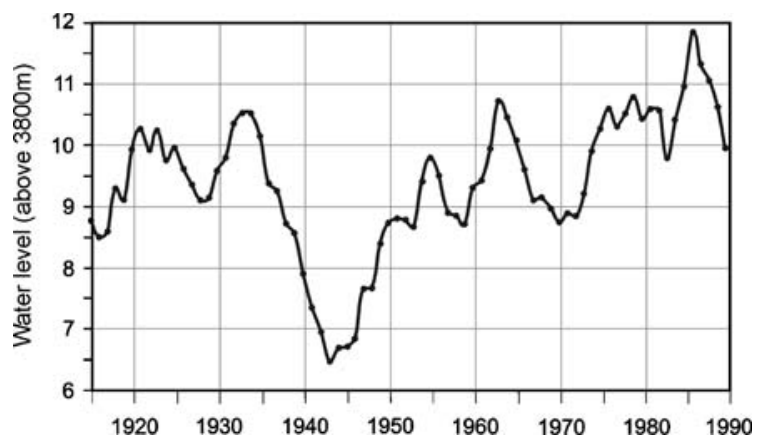

Fig. 6 Water-level fluctuations of Lake Titicaca, measured at Puno (modified after Pawley et al., 2001)

that the quillwort Isoetes occurred during the pleistocenic low-water periods; however today, it occurs only in lakes in higher regions of the Titicaca catchment (Ybert, 1992). The recent macrophyte vegetation is characterized by submerged Myriophyllum and extensive "totora" bulrush belts (Schoenoplectus californicus ssp. tatora) stands, which form the basis for traditional management practices (Villwock, 1993).
Lake Chad is a shallow lake in an endorheic basin in the semiarid Sahel Zone of northern Africa (Fig. 7). The lakeshores and shallow water areas are covered by aquatic macrophytes. Its climate is characterized by a pronounced annual dry and wet season that results in annual water-level fluctuations of about $1 \mathrm{~m}$ (Fig. 8A). Because of the shallow landscape gradient, large areas fall dry during low-water periods, consequentially favoring terrestrial herbivores and insectivores. With the onset of the rains water levels rise, and macrophyte growth in the mud flats is accelerated due to the release of nutrients that were recycled during the low-water period. The new habitats are quickly occupied by aquatic fauna. Lake Chad receives water both from direct precipitation and from the southern LogoneChari Rivers. The adults of many fish species of the lake perform extensive reproduction migrations to the rivers and their floodplains (Carmouze et al., 1983). In the 1960s Lake Chad had an area of more than $26,000 \mathrm{~km}^{2}$, making it the fourth largest lake in Africa. 


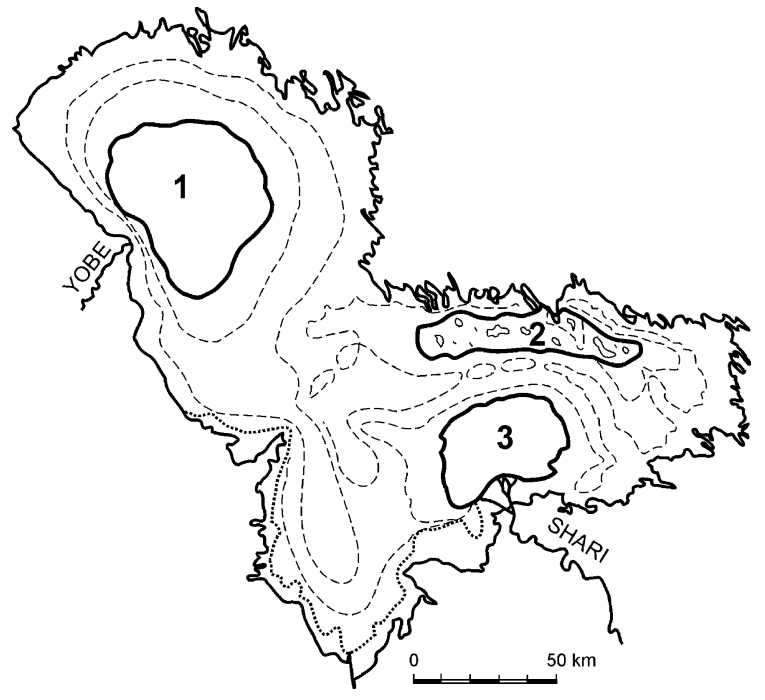

Fig. 7 Recession of Lake Chad after 1972, and development, as of 1975, of different facies in the surviving parts of the lake, based upon aquatic plants and phytoplankton. (1) Evolution towards a natron pond; (2) Towards a swamp; (3) Towards a river delta (modified from Carmouze et al., 1983)
In the 1970s, a drop in water level had caused a separation of the lake into two subbasins (Fig. 8B). By 2000 , its size had decreased to less than $1,500 \mathrm{~km}^{2}$. This is due to reduced rainfall combined with a greatly increased demand for irrigation water which was being drawn from the lake and the rivers which feed it. The largest of these is the Logone-Chari River system. The probability exists that Lake Chad may shrink further and perhaps even disappear altogether in the course of the 21 st century.

\section{Water-level fluctuations (WLF) and floodpulsing in lake systems compared to rivers}

Some definitions

In a graphical plot, a fluctuating water level in a natural water body appears more or less like a sinoidal curve (Fig. 9). All properties of the curve can be used to define the qualities of the changes: the steepness of rise
Fig. 8 (A) Long-term trend of annual minimum and maximum water levels in Lake Chad (Evans \& Mohieldeen, 2002). (B) Effects of Lake Chad's recession during the 1970s. At first, the two basins separate, later, the north basin temporarily dries up, while the south basin almost regains its original depth (modified from Carmouze et al., 1983)
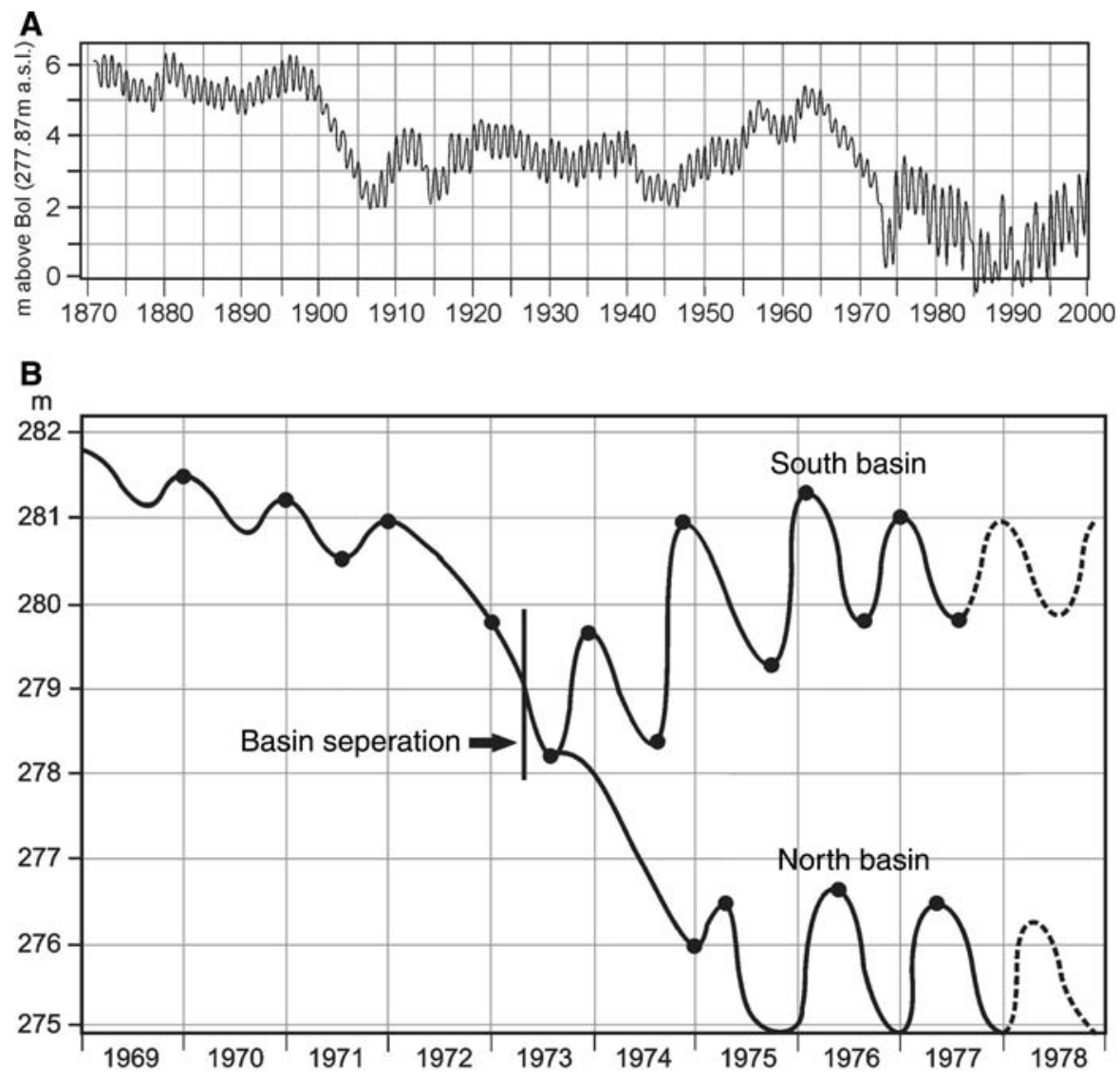


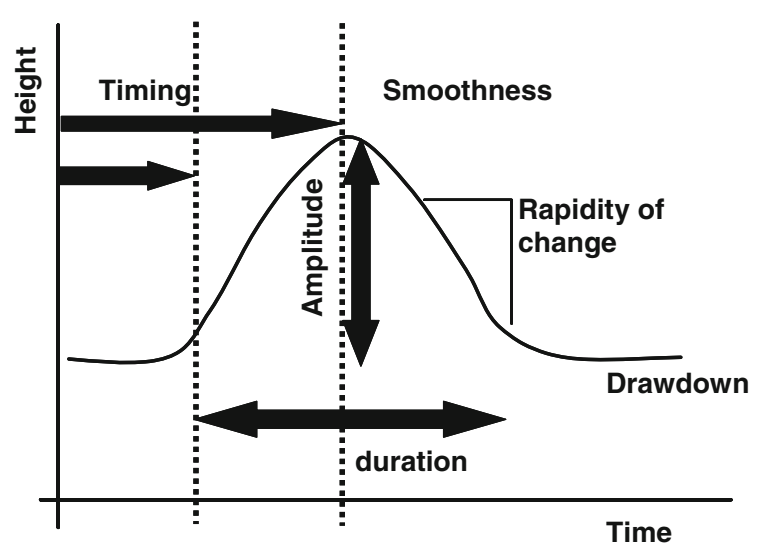

Fig. 9 Characteristics of a floodpulse (strongly modified after Welcomme \& Halls, 2001)

and drawdown, the total duration, the amplitude, and the frequency by which it recurs (Puckridge et al., 1998). To be able to define interferences to the life cycle of the biota by flood/drought events, it is important to analyze the resilience of organisms to such changes ("phenological window of susceptibility") and/or their ability to use floodborne resources at that time ("window of opportunity," Gafny \& Gasith, 1999; Junk \& Wantzen, 2004).

Water level fluctuation (WLF) is a neutral term that is not limited by any of these dimensions. As shown elsewhere (Hofmann et al., this issue), in extreme cases a WLF can be as short as seconds (in the case of waves) or last centuries (in the case of lake drawdown). An analogy: the spatial dimension can range from millimeters to hundreds of meters. In our paper, we want to limit the scope of water-level fluctuations to those events that are within the temporal and spatial scale of most living organisms, i.e., limit the temporal dimension to a range from hours to several years, and the spatial (vertical) dimension from several centimeters to meters of water level. In the transverse dimension, the same flood size can translate into a small or large extension of flooded area (Aquatic-Terrestrial Transition Zone, ATTZ), depending on the slope of the landscape. Because the term "flood pulse" has gained wide acceptance in international ecological literature for similar phenomena in rivers, we will adopt this term here; however, we will stress the differences between river and lake flooding. Moreover, there may be recurrent patterns that are responsible for interannual variation which we term "multi-annual patterns."
Water-level fluctuations in rivers and lakes

Do floods and droughts affect rivers and lakes in the same way? There are distinct properties in each system type, such as the unidirectional flow and the higher kinetic energy of river water, which has consequences for transport and turnover of sediments and solutes. Aquatic-terrestrial interactions tend to be more intensive in rivers than in lakes as they are more tightly intertwined with their catchments. The oblong shape of rivers makes them perfect corridors in the landscape to favor gene flow between remote areas, compared with the generally more or less rounded shape of lakes.

On the other hand, there are some general patterns concerning processes and effects during the cyclical rise and fall of water that occur in the AquaticTerrestrial-Transition Zone (ATTZ) of any freshwater body. During rising water levels, habitat conditions worsen for terrestrial animals and plants. If the pattern of flooding is predictable (i.e., occurring during a predictable time of the year), terrestrial organisms of floodplains may have adapted their lifecycles to cope with these adverse conditions, either by producing water-proof propagules and resting stages, or by migrating into non-flooded areas (see reviews on plants by Bornette \& Amoros, 1996; Gurnell et al., 2003 and for invertebrates by Adis \& Junk, 2002). Aquatic organisms can then occupy these habitats, many of which make use of floodborne resources such as drowned terrestrial organisms, fruits from floodplain trees, and primary production in floodplain water bodies (Junk, 1985; Bayley, 1991; Wantzen et al., 2002). Such flooding triggers the development of a highly complex habitat mosaic with sites of variable stages of succession and with steep gradients in ecological factors (e.g., oxygen saturation, salinity, temperature, flooding period, current) in the floodable areas (Amoros \& Bornette, 2002; Poole, 2002; Ward et al., 2002; Wantzen et al., 2005a); however, floods may also homogenize the characteristics of otherwise uncoupled water bodies (Thomaz et al., 2007). Generally, biodiversity is higher in the ATTZ than in a permanent water body (Tockner \& Ward, 1999; Ward et al., 1999; Junk et al., 2005; Marchese et al., 2005). Organic and inorganic matter that becomes dissolved or suspended during rising water levels causes increased turbidity and release of nutrients from the rewetted floodplain. Moreover, 
waters conveyed by floods often contain dissolved and particulate-bound nutrients from catchments that additionally enhance the productivity of floodplains. These floodborne nutrient inputs may cause an increased growth of algae and macrophytes. During later stages of succession in floodplains, algae may be outcompeted by aquatic macrophytes due to their more efficient shadowing, release of allelochemical substances, and nutrient uptake by macrophytes. This causes "alternating stable states" also found in shallow lacustrine environments (Scheffer \& Jeppesen, 1998). Large proportions of organic carbon may become accumulated during the aquatic phase in the ATTZ due to mostly anoxic conditions in the sediments (Nogueira et al., 2002). In rivers, feeding on terrestrial resources and floodborne primary production by floodplain species compared to permanent river channel dwellers causes a better growth rate known as "floodpulse advantage"(Bayley, 1991).

During decreasing water levels, these processes become partly inverted, i.e., aquatic organisms migrate back into permanent water-bodies, and the stranded aquatic substances become used by terrestrial organisms (Adis et al., 2001; Junk \& Wantzen, 2004) or mineralized by microbes. It is remarkable how fast flooding and drawdown may mobilize a large part of the available carbon and nutrients in the ATTZ (Nogueira et al., 2002). This "system-reset" mechanism is especially effective in shallow floodplains that oscillate between flooded and arid conditions, e.g., in tropical and subtropical zones (Wantzen \& Junk, 2006). The steep redox gradients of the floodplain sediments that support a vivid microbial activity are triggered as well by the regular changes between wet and dry conditions (Boon et al., 1996).

While these processes are increasingly well understood in pulsing river-floodplain-systems, there is a large demand for information on pulsing lakes. This is largely due to the fact that most lakes (e.g., in Central Europe) have been regulated for centuries, and therefore, reference conditions of natural flooding and drawdown are hardly known. On the other hand, many classical studies of lakes have considered these ecosystems as closed systems that hardly interfere with their terrestrial environment ("The lake as a microcosm," Forbes, 1887), or the open water column has been studied isolated from its benthic and littoral zones. Indeed, the water volume stored in the littoral zone is often negligibly small compared to the open water zones, but current research indicates that the contribution of the littoral zone to the whole organic matter turnover is disproportionally high compared to the central part of the lake (Sala \& Güde, 2006). Most lakes, if not all, are heterotrophic, i.e., dependent on the organic inputs from their catchments (Sobek et al., 2007), and it is especially so for their floodplains.

\section{Landscape gradient}

The degree by which floodpulses interfere in ecosystem processes of flooding systems compared to regulated systems (see discussion in Junk \& Wantzen, 2004) depends very much on landscape morphology. For example, in steep rocky valleys, such as alpine lakes and reservoirs, the ATTZ is only scarcely developed and the number of biota affected by WLF is small even during larger fluctuations (Fig. 10A). Conversely, shallow littoral zones of lowgradient landscapes provide much more space for aquatic-terrestrial interactions, as larger areas become flooded. This is the case, e.g., in the Untersee of Lake Constance, and in shallow lakes, e.g., Lake Chad or the Neusiedler See (Fig. 10B). Most of these lakes have large reedbelts (see Scheffer, 2004 for further case studies). Many lakes have elements of both deep and shallow lakes, e.g., Lake Titicaca or the Obersee part of Lake Constance (Fig. 10C). These lakes have a deep lake basin with steep sublittoral slopes, but the eulittoral zone includes shallow slopes that bear extensive floodplain areas. In this situation, extreme fluctuations may trigger a die-back of the floodplain vegetation by drought or unusually high floods (Schmieder et al., 2004). Most lake types, however, have a slope that is intermediate between these extremes, that is, the water-level fluctuations cover a moderately steep gradient so that the biota may migrate along the ATTZ (Fig. 10D). These patterns are basically the same for rivers and lakes.

\section{Catchment linkages}

Apart from the landscape gradient, there are several other morphological metrics that describe the morphological linkages between the lake main water body and its ATTZ. Due to the limited length of lakes, several of these metrics ranges are of lower 

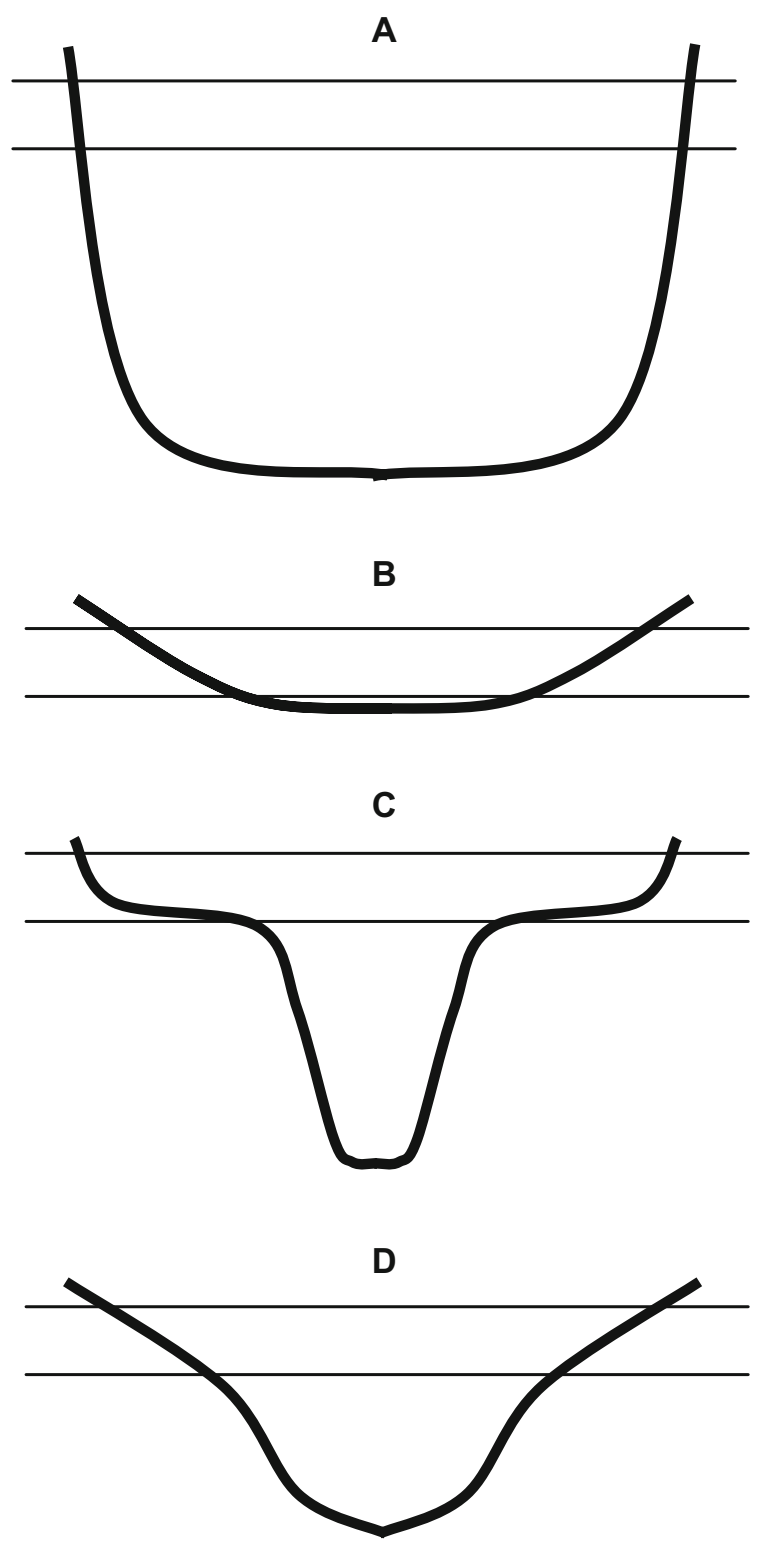

Fig. 10 Morphological lake types with different importance of water-level fluctuations (minimum and maximum water levels indicated by horizontal lines): (A) Large, deep lake with steep banks, (B) Shallow lake, entirely influenced by the floodpulse, (C) Combined type of A and B with deep central trough and extensive shallow floodplains, (D) "Average" lake with moderate floodplain area and permanent central trough

dimensions in lakes compared to rivers (e.g., basin diameter, basin perimeter, basin shape, compactness ratio, shoreline development; see Wetzel, 2001, for a comprehensive comparison of lake and river systems). The catchment aspect is especially important for the lake-river comparison. Lakes rarely integrate over such a large range of areas with heterogenous geochemistry (reflecting in water quality), rainfall patterns (floodpulse patterns), and biogeographical units (species exchange) as rivers do. Consequently, lakes receive much less heterogenous sources of water, dissolved and suspended solids, and allochthonous organic matter than rivers. On the other hand, lakes may reflect regional rainfall patterns better than rivers, although real-world conditions may vary strongly from these hypothetical considerations due to regional climatic patterns, and the way water accesses the lake. Large shallow lakes with a high amount of on-site rainfall and lakes with a strong riverine influence will have more pointed hydrographs than those fed mainly by diffuse inflow from groundwater and riparian wetlands (Fig. 2).

Temporal patterns of the floodpulses

Like in rivers, flood pulses in lakes may be multimodal (i.e., many flood events per year) or monomodal. They may be predictable (i.e., occurring at a given time, e.g., snowmelt events in spring) or unpredictable (e.g., effects of a strong summer rain). Regional climatic patterns affect riverine and lacustrine floodplains in similar ways, notwithstanding the general differences in their linkages to the catchments described above.

Lakes have a much higher residence time than rivers. Therefore, multi-annual patterns have a much stronger influence on the habitat structures of the ATTZ of lakes compared to rivers. In deep lakes with shallow floodplains (Fig. 10C), long-term low-floodyears may cause a disconnection of the floodplain from the main water body and a die-back of the aquatic flora and fauna (see case study of Lake Titicaca). Longer periods of high-flood-years (including higher water levels during the "low-water period") in turn may raise the organic matter belts in floodplain zones of lakes and create a "floating littoral" including riparian vegetation. This phenomenon has frequently been observed, e.g., in lakes that were artificially impounded or in floodplain lakes of naturally oscillating areas (Wantzen et al., 2005a).

Hydraulic forces

The main difference between flooding riverine and lacustrine systems is the (mostly) unidirectional flow 
in rivers compared to the multidirectional and weaker currents in lakes. This difference reduces the predictability of the occurrence of hydraulically shaped habitats in lakes.

Both rivers and lakes have erosional and depositional sites; however, their arrangement is different. In rivers, the low-order sections are generally erosional, the mid-river sections have a balanced ratio of erosional and depositional sites, and the lowermost sections and deltas are mostly depositional. Floodpulses shape the "riverscape" (Ward, 1998; Allan, 2004) by creating and abandoning meanders and their substructures (e.g., Wantzen et al. 2005a). There are no analogous structures in lakes, apart from those that are created by riverine activities (oxbow-lakes). In lakes, the position of erosional and depositional sites is defined by the main wind direction and internal currents (which may be influenced by tributary rivers). Due to this difference, the habitat dynamics and the attainable diversity of floodplain habitats are higher in rivers than in lakes.

In rivers, particulate organic matter and suspended inorganic sediments either become accumulated in the lentic zones of the main channel, in the floodplain, or they become transported downriver. The analogous sites in the lake littoral are depositional lake ends that receive large amounts of sediments from tributaries, and bights that accumulate wind-driven particles. Hydrological events that mobilize these sediments in rivers are generally flood events known as "system reset flooding" (see Wantzen et al., 2005a), while in lakes additional wind forces are needed to develop sufficient water movement. Due to tighter aquatic-terrestrial linkages, the overall inputs of inorganic and organic substances are much higher in rivers than in lakes; therefore, the development of floodplains (and the process of terrestrialization with inorganic sediments in floodplain water bodies) is much faster in rivers. For example, the deposition of drifting large woody debris often acts as condensation nuclei for sediment accumulation in rivers (Gurnell et al., 2001). However, backflooding in river mouths of tributaries often creates organic matter-rich depositional sites (that can become part of the ATTZ) in a similar fashion for both rivers and lakes.

Due to the reduced current in lakes compared to rivers, the sediment structure of the ATTZ may differ tremendously between both system types. The current in rivers permanently mobilizes the fine particles, creating an upstream-downstream sorting of grain sizes. In lakes, the zone that is exposed to waves for the longest time of the year has the coarsest sediments, while the average grain size decreases with wave exposure (i.e., downwards on the floodplain gradient). During drawdown in lakes, the moving surf-zone touches very different types of sediments than those that result from a zonation during the high-water phase. For deep lakes with an extensive eulittoral zone, this phenomenon has important consequences for littoral currents and for deposition patterns. In the Upper Part of Lake Constance, fine-grained sediments become suspended in the surf-zone during the low-water period and are locally transported to the edge of the steep sublittoral zone. Because the sediment-loaded water has a very high density, it plunges down into the profundal zone thereby co-precipitating organic matter particles and bacterial "lake snow" (Grossart \& Simon, 1998). Sediments of different depth zones may also be chemically different so that the surf zone mobilizes variable qualities and quantities of dissolved substances during changing water levels.

\section{Influences of floodpulses on the ecology of lakes}

\section{Element cycles and productivity}

Floodpulses represent biochemical hot moments (McClain et al., 2003) for the ecosystem. The timing of the flood cycle during the activity period of the biota is crucial for the biologically mediated matter turnover (Wantzen \& Junk, 2006).

During the flood phase, several processes facilitate the deposition and temporal storage of organic matter in the ATTZ of lakes. Apart from drowned terrestrial biomass, rising water collects the organic matter that has become deposited during a drought and carries it to the surf zone. This terrestrial leaf litter becomes degraded by waves and is then contributed to the littoral zone as FPOM (see contribution by Pabst et al. in this issue). In the shallow and light-penetrated littoral zones, benthic algae and aquatic macrophytes are fertilized by nutrients from terrestrial mineralization thus producing additional ("floodplainautochthonous") biomass. Large amounts of organic matter derived from pelagial phytoplankton become 
deposited or reused in the flooded sediments. The retention of seston in the littoral is fostered by adhesion of particles on sticky biofilm surfaces and by the current-reducing effect of the macrophytes. In carbonate-rich lakes, macrophytes, especially characean algae, precipitate calcium carbonates which create a matrix of fine organic and inorganic particles (Kufel \& Kufel, 2002). Below the oxidized surfaces of these sediments, there are anoxic layers that temporarily store or release large amounts of reduced carbon compounds. Studies in Finnish lakes have shown that there is a close interplay between vegetation type in the littoral and the changes of net productivity due to flooding of the ATTZ: high water levels may decrease productivity due to reduced production of biomass; however, net productivity may increase at other sites where decomposition of litter is reduced due to high water levels (Larmola et al., 2004).

During drawdown, large areas of organic sediment deposits become exposed to light and air. In northern temperate lakes, such as Lake Constance, the drawdown occurs in autumn when most of the allochthonous leaf litter inputs take place. Frost and wave action break down this organic matter into small particles that are either carried into deeper zones of the littoral or remain in the dry zone. In other systems, e.g., in Mediterranean climates, the drawdown occurs during the vegetation period. Here, macrophytes become stranded and consumed by the terrestrial biota or are mineralized. The drawdown also lowers the pressure of the surface water body on the surface-near groundwater layers. Consequently, groundwater seepage into the littoral zone becomes strongly enhanced. The dissolved (mostly reduced) organic and inorganic substances of these outflows locally enrich the remaining lake water and may cause considerable algal and bacterial growth. These seepage sites can be easily visualized by the mass occurrence of algae or iron-oxidizing bacteria, especially in the area below extensive reed belts. Rainfall on exposed sediments can mobilize large amount of nutrients and increase the already-high nutrient concentrations in the remaining water bodies, especially in reservoirs (Geraldes \& Boavida, 2004).

\section{Biodiversity patterns}

The permanent change between dry and wet conditions affects the biodiversity patterns of biota in the
ATTZ of lakes in several ways. First, the alternating of habitat characteristics allows a sequential use of a given habitat by different species. This means that although the diversity of a biotic assemblage at a given time may be low, the chronological sequence of different assemblages during an entire flood cycle may yield a very high biodiversity (Junk \& Wantzen, 2006). Flooding creates a spatiotemporal mosaic of connected and unconnected water bodies that are beneficial for the co-occurrence of organisms, e.g., shallow-water refuges for small animals that are otherwise heavily predated by fish. Especially in lakes, the size of sediment particles varies with depth along the ATTZ and variable water levels precede over variable physical habitat structures (Beauchamp et al., 1994; Gasith \& Gafny, 1998). Gasith et al. (2000) showed that fish in Lake Kinnereth vary their habitat preference according to water-level fluctuations, as their risk of predation depends on sediment size.

Secondly, the pulse shape changes between years (Fig. 9). This allows a meta-effect on diversity. In different years, different groups of organisms may be successful, considering their windows of opportunity (Gafny \& Gasith, 1999) and phenological windows of susceptibility (Junk \& Wantzen, 2004). In Lake Constance, different flood situations have been shown to trigger the occurrence of various plant strategies (Peintinger et al., 2007). For example, the endemic forget-me-not (Myosotis rehsteineri) flowers only during the low-water phase and focuses on survival during sediment shifts of the flood phase (Schulz, 2007). In years with intensive water-level fluctuations, this species is very successful; however, in consecutive years of low water level, it is nearly outcompeted by purely terrestrial plants.

Another potential reason for a high biodiversity in the ATTZ compared to other habitats is that the ATTZ represents a switchboard of aquatic and terrestrial conditions that can be colonized by both aquatic and terrestrial "visitors" and by an autochthonous fauna and flora (Junk \& Wantzen, 2006). This theoretically high number, however, may be reduced in the case of severe stress which acts differently for different biotic groups. Wisheu \& Keddy, (1992) have developed a centrifugal model for the distribution of shoreline wetland plants that includes both the gradients of distribution and the competitive processes between the species. Several 
authors have highlighted the importance of the intermediate disturbance hypothesis (Connell, 1978) for the assessment of the effects of floods in freshwater systems (e.g., White, this issue, WitthöftMühlmann et al., 2002). The hump-shaped biodiversity curve indicates that the highest co-occurrence of species is possible at a moderate level of disturbance which results in a reduction of competition, but that does not exercise a severe physical stress on organisms (Ward \& Tockner, 2001).

Floodpulse adaptations of lake littoral species

Adaptation of species traits to floodpulses requires that either the species encounters a somehow predictable floodpulse (e.g., a monomodal floodpulse, or a set of polymodal pulses occurring at the same time of the year) or the floodpulse pattern occurs over a sufficiently long enough time to evolve adaptations (Junk et al., 1989). We argue that adaptation to floodpulses represents a selection advantage for riverine species colonizing the littoral zones of lakes and vice versa. Mass mortality of the clam Corbicula fluminea in Lake Constance during winter drought is an example of how an invasive species can become hampered by water fluctuations (see Werner et al., this issue). On the other hand, the invasive amphipod Dikerogammarus villosus migrates into greater depths of the lake during winter drought that affects the upper littoral zone and has been shown to be a successful invader of Lake Constance (Hesselschwerdt \& Wantzen, unpublished manuscript).

The occurrence of macrophytes is strongly controlled by water-level fluctuations, especially in shallow lakes (Beklioglu et al., 2006). Many floodpulse-adapted species have survival strategies that include production of drought-resistant seeds, escape from drought via apical meristems that are released during autumnal storms (e.g., the water weed Ceratophyllum demersum), or a sequestration of nutrients into drought-resistant tubers before water levels drop. Sensitive phases during life cycles are still not fully understood. For example, a long-term study on the vegetation of the ATTZ of Lake Constance revealed that of two specialist species, Ranunculus reptans showed a positive effect during flooding but not Littorella uniflora (Peintinger et al., 2007). Reed (Phragmites australis) is generally adapted to flooding; however, reed belts were severely damaged by an extraordinary flood in 1999 (Dienst et al., 2004). Apart from direct impacts (e.g., water stress, oxygen stress), WLF may indirectly affect even floodpulse-adapted species. In reed belts, high water levels and high water temperatures during summer floods foster the development of pathogenic fungi, which may kill the reed plants (see paper by Nechwatal et al., this issue).

Flooding is a strong selector for woody plant species in the ATTZ (Keogh et al., 1999; Nunes da Cunha \& Junk, 2001; Wittmann et al., 2004); therefore, only species equipped with a number of adaptations to flooding are found in these systems (Waldhoff \& Junk, 1998; Waldhoff et al., 2002; Parolin et al., 2004). Once the root systems are flooded and become anoxic, trees switch from respiration to alcoholic fermentation, which reduces the energetic yield (Kreuzwieser et al., 2004). Apart from direct oxygen stress, anaerobic soil conditions also foster denitrification, which favors the existence of tree species with nitrogen-fixing symbionts, e.g., Alnus glutinosa in Central European lakes (Nickel et al., 1999). These physiological constraints limit the occurrence of trees in flood zone; therefore, Keddy and Fraser (2000) use the tree line to delineate the ATTZ of lakes.

Terrestrial invertebrates can escape flooding by vertical or horizontal migrations, or they remain in the flooded habitat in a flood-resistant life stage. Flood drives many terrestrial species out of their refuges making them an easy prey for predators and scavengers just above the surf zone (e.g., hunting spiders, carabid, and cicincelid beetles). While these phenomena are relatively well understood in river floodplains, especially in the tropics (see Zerm \& Adis, 2000; Adis et al., 2001; Adis \& Junk, 2002; Paetzold et al., 2005), studies from lakes are scarce (Strand, 2005). We expect that due to the smoother shape of the floodpulses in lakes compared with those in rivers, flood-adapted terrestrial migrators (that evade the flooded area) suffer less from floodpulsecaused mortality in lakes than in rivers. Consequently, the number of scavengers specialized in feeding on carcasses that accumulate at the surf zone should be lower in lakes.

Several studies have shown that aquatic invertebrates clearly react to floodpulses in lakes (see contributions by White et al., Baumgärtner et al., and Brauns et al., this issue). Many benthic 
invertebrate species are able to survive in the upper part of the flood gradient during droughts and may profit by the warm and predator-free conditions during early flooding. For example, eggs of the mayfly larvae of the genus Ecdyonurus survive winter droughts above the water level and use the small ponds in the upper zone of the ATTZ in Lake Constance for the development of early larval instars (Wantzen et al., 2005b). The same occurs with the most common mosquito of Lake Constance, Aedes vexans. This species oviposits on moist soils just above the surf zone. Consecutive years of decreasing flood maxima may then cause the accumulation of large egg banks, as eggs may survive several years. If these years are followed by a high flood that activates these egg deposits, catastrophic mass emergences of mosquitoes may occur (Kless, 2003). Adults of other aquatic insect groups were regularly observed ovipositing directly on the already dry-fallen parts of the ATTZ of Lake Constance, e.g., several species of the dragonfly genus Sympetrum and of the dipteran genus Tipula (KMW, pers. obs.).

When water levels rise, many fish species quickly colonize the flooded ATTZ either to find food resources for themselves or their offspring (Welcomme, 1979; Bayley, 1991; Wantzen et al., 2002) or adequate spawning sites (Humphries \& Lake, 2003). In Lake Kinnereth, Gafny et al. (1992) could show a direct dependence of the fish species Mirogrex terraesanctae on the water-level fluctuations that provide algae-free, clean stone surfaces for their adhesive eggs.

High trophic-level organisms such as birds and mammals have received much less consideration in recent WLF-related studies (see review paper by Leira \& Cantonati, this issue); however, there is a large database on wading bird species that depend on the floodpulse for foraging in shallow waters and exposed sediments, and for breeding on the dessicated ground (e.g., Erwin, 1985; David, 1994).

The impact of multi-annual flood pulses on lakes: a comparison between Lakes Chad and Titicaca

Multi-annual patterns of several (2-100) consecutive years of higher or lower WLF ranges are crucial for the establishment or local extinction of species in the ATTZ. Drivers for this multi-annual climate variability vary regionally, e.g., ENSO phenomena in
South America, the Sahelian Precipitation Anomaly in North Africa, and the North Atlantic Oscillation (NAO) in Europe (Blenckner et al., 2007). Large rivers and large deep lakes recover relatively quickly from these events, because water masses are large and subpopulations of plants and animals can find refuges for surviving such a critical period, but shallow lakes or lakes with extensive shallow margins (Type B and C, Fig. 10) may become seriously affected, as shown by a comparison between Lake Chad and Lake Titicaca.

Lake Chad is affected by Sahelian precipitation anomalies (Thompson, 1996). Every couple of decades, multi-annual extreme droughts hit the Sahel Zone (Fig. 8A). During these periods, the lake area shrinks dramatically as shown in the drought that started in 1972, (Dumont, 1992). In 1965-1968, during a multi-annual wet period, the lake covered an area of $18,000 \mathrm{~km}^{2}$ with a mean depth of $4 \mathrm{~m}$ and a maximum depth of $12 \mathrm{~m}$. In 1972 an exceptionally strong drought period began. When a certain water level was reached, the lake basin split into a northern and a southern basin (Fig. 8A, B). In the northern basin that has only insignificant tributaries, the water level resided about $3 \mathrm{~m}$. Transparency decreased from $90 \mathrm{~cm}$ to $10 \mathrm{~cm}$ and electric conductivity increased. Because of high evapotranspiration rates, the water accumulated mineral salts, and during the dry season the lake reduced further to a series of temporary natron pools. The southern basin continued as a comparatively small lake because it received water from the southern Lagone-Shari Rivers, but its water level fluctuated annually by about $2 \mathrm{~m}$ (Fig. 8B). At the beginning of the next wet cycle in 1976, the southern basin covered an area of about $6,000 \mathrm{~km}^{2}$, but the northern basin remained dry.

During the following 4 years the aquatic macrophyte covering the lake basin expanded about fivefold and algal biomass increased but the diversity decreased. Salt-intolerant species such as Cyperus papyrus were reduced. In the saline northern basin a species-poor algal community established itself that was dominated by very resistant and toxic Cyanobacteria. As a result, zooplankton diversity decreased. Increased silt loading led to a reduction of bivalves. Mass mortalities of fish occurred, and several species became locally extinct. Within one year (1974) species richness in the fish community dropped from 34 to 5-8; only those species showing high tolerance 
to low oxygen concentrations and high feeding plasticity survived. After 1976, Lake Chad seemed to stabilize at a new level, but in the 1980s a new extended drought started that lasted about 10 years. In 1984, the southern pool shrunk to a size of only $2,000 \mathrm{~km}^{2}$. From the mid-1990s increasing rainfall led to a rise in water level (Fig. 7) and late 1999 saw the heaviest rains in central Africa in the last 30 years. Since 1973, the annual flood amplitude is about twice as high as it was before (Dumont, 1992).

This example shows that multi-annual large changes in hydrology can represent a heavy stress factor in shallow lakes, especially when the water level is decreasing. If this stress situation occurs over a period of a few years only, abundance patterns shift towards species that can survive in refuges or resting stages in the sediment. The other species return once the lake regains its original setting. Such environmental changes may even increase habitat diversity and species diversity in comparison with stable systems through the control of populations of highly competitive species. However, if the stress increases towards desiccation and surpasses the thresholds of the system, local extinction of species may occur in a very short period of time, as shown in the northern basin of Lake Chad.

The capacity of recovery of those lakes depends on the available refuges, for instance, in permanent swamps in their surroundings and especially on feeder rivers where relict populations of the lake fauna can survive. Recovery will require years or decades depending on the complexity of the communities and the level of specialization and may even lead to a new biocoenosis. For Lake Chad, Dumont (1992) postulates a simplification of the biocoenosis because of an increasing number of multi-annual droughts. The fact that shallow lakes have almost no endemic species points to the relative frequency of such heavy disturbance events. A similar reaction to multi-annual dry and wet periods can be observed in large tropical and subtropical wetlands, e.g., the Okawango Delta in Botswana (Ramberg et al., 2006), the Central Delta of the Niger River in Nigeria, (Lae, 1994), and the Pantanal in Brazil (Junk et al., 2006). Diversity of aquatic species is maintained by the connection with large river systems that act as refuges for wetland subpopulations.

Even in deep lakes annual and multi-annual fluctuations may affect at least parts of the system as shown for Lake Titicaca. There are two major shallow areas in the lake: the subbasin Lago Pequeno and the Puno bay. The annual water level oscillations of $1 \mathrm{~m}$ have little impact on the lake and the ATTZ, but there are also multi-annual water level changes related to El Nino phenomena (Fig. 6, Pawley et al., 2001). In the first half of the 20th century, the difference between the highest water level in 1933 and the lowest water level in 1943 reached about $4 \mathrm{~m}$. This difference had a strong impact on the shallow water areas. During the high-water period, the harbor of Puno, the rail road, and the adjacent plains were inundated and the harvest destroyed. During extreme low-water levels large shallow areas along the shores fell dry and nearly all stands of the bulrush totora (Schoenoplectus californicus ssp. totora) dried out. In the Puno subbasin alone, 23,000 ha of totora swamps were destroyed with negative economic consequences for the local population that uses the plants for boat and roof construction and as food item. There were dramatic effects on the Uru people who lived in the totora swamps and whose social structure became disintegrated when they had to leave the drying swamps (Monheim, 1956). In 1986, during the peak of the multi-annual high-water period, the Chara stands and the deep water Potamogeton stands in Lago Pequeno died because of reduced light conditions. The decomposition of large amounts of organic matter led to anoxia and the death of benthic animals. When the lake level decreased, Chara stands quickly re-established but not the deep water Potamogeton stands. In Lago Grande, lake level rise had little effect on the macrophyte stands, because of higher water transparency.

The ecological consequences on the lake have not been studied in detail, but the following hypotheses can be established. Lake Titicaca is an oligotrophic lake with very low algal production as indicated by a secchi depth of up to $10 \mathrm{~m}$. A considerable part of aquatic primary production takes place in shallow water areas that are colonized by dense stands of emergent and submersed aquatic macrophytes. These stands are important habitats and spawning grounds not only for the endemic fish subfamily Orestinae, but also for birds and amphibians (Pawley et al., 2001). Fast changes in water level of several meters considerably reduce the productive area and the habitats for the aquatic fauna because the plants cannot adjust their distribution quick enough to offset the changing hydrological conditions. 


\section{Floodpulses in lakes and man}

Ecosystem services of an intact ATTZ and a natural floodpulse regime in lakes

The floodplain zones of lakes generally fulfill the same ecological functions and ecosystem services as the riverine ones do (Manring, 2005; Bohensky et al., 2006). The most prominent ecosystem services of lake floodplains are:

- climate buffering

- flood control

- buffering of allochthonous nutrient inputs

- storage and release of carbon compounds

- self-purification of water

- sites of increased plant and bacterial productivity

- sites of reproduction, feeding and growth of invertebrates, fish, amphibia and birds

- sites of high biodiversity, including endemic and rare species

- tourism/recreation/aesthetic value

In lakes that are aligned with river courses, the function as hydrological buffers is especially important. The ATTZ of these lakes acts as a reservoir that dampens the discharge of the rivers. For example, Lake Constance buffers a considerable part of the floods that affect the cities along the Rhine river.

The positive effects of enhanced primary production and fish productivity in floodplain zones of lakes has been shown mostly for tropical lakes (e.g., Lim et al., 1999; Welcomme \& Halls, 2001). The case studies of the Chad and Titicaca lakes have shown how entire human social groups depend on the functioning of the ATTZ of lakes. In temperate lakes it can be assumed that flooding is equally or even more important than in the tropics, as the shallow floodplain waters heat up disproportionally compared to their deeper water bodies (Güde et al., 2004).

The importance of lake floodplain zones as temporary carbon storage sites is still severely underestimated in global climate models. Although it is evident from the occurrence of deep black sediment layers (consisting largely of organic carbon) in the ATTZ, they are rarely mentioned in climate models. A recent study on small water bodies in the US has shown how important these aquatic habitats are for the storage and release of carbon (Euliss et al., 2006).
Lake management

Human activities interfere with natural hydrological regime of lakes in several ways. On a local scale, the natural fluctuations of lakes have been reduced by regulation of the lake in- and outflow. Many lake floodplains in the "developed" countries have been isolated from their main water bodies. Moreover, damming has created a number of new lakes with management schemes that often differ strongly from natural WLF. On a regional scale, sealing of the surfaces by urbanization and systematic regulation of all tributaries has led to an increased flashiness of lake hydrographs, as the buffer function of the ATTZ has been cut off, and all regional precipitation immediately arrives in the main water bodies. On a global scale, climate change effects interfere strongly with the water regime, due to extended drought periods and increased probability of storm flow events (IPCC, 2001).

The management of water levels in lakes follows several principles: (i) to keep the water level high until an increased demand for water (drinking water, hydroenergy) occurs, (ii) to keep the water level permanently low in order to gain land from the ATTZ, (iii) to keep the water level stable on an average level in order to guarantee flood-protection and permanent navigability due to stabilized water levels in river channels that connect lakes. Principle I is valid for many Mediterranean lakes and for dams. In the Mediterranean region, however, lakes have suffered a permanent drawdown in the past years due to lacking rainfall and an increased demand on drinking water for a growing population (e.g., Lake Kinnereth, Gasith, pers. comm. and see Beklioglu et al., 2007). As an example for Principle II, many lake levels have been lowered in the medieval period in order to gain fertile land in Central Europe (e.g., "Federsee" in Southern Germany) or to create permanent access to islands (e.g., Greater Plöner See, Northern Germany).

Many examples for Principle III are known from prealpine lakes which were stabilized to protect the cities at the lake margins. The old sluices in the cities of Luzerne and Zurich (Switzerland) give impressive proof of the tradition of water level regulation. Considering the current climate change effects, principle III is likely to become increasingly important because many more lakes than before will be 
included in flood and drought management schemes. Now that climate models have gained sufficient predictive power, efforts are strongly needed to improve our knowledge about these effects and to develop scenarios of how to deal with it on the landscape planning level. It follows clearly from the arguments delivered above that the preservation of still-existing floodpulse regimes and of the ATTZ in lakes should become first priority in lake management schemes. Moreover, already-existing regulated lakes (e.g., dam lakes) may either be deregulated or regulated in a management scheme that reduces environmental impacts. The REGCEL project from Finland (see contributions by Aarovita et al., this issue) is a positive example of how winter drawdown can be limited or regulated according to requirements of natural populations.

\section{Climate change}

Climate models predict an increase of stochastic events (unpredictable floods and droughts) and a reduction of so-far predictable elements of the hydrologic regime (snowmelt and summer drought). Moreover, a general trend towards drier conditions can be anticipated for many regions worldwide, thus creating multi-year low water phases as discussed above. Current trends within long-term series, e.g., for Lake Constance, indicate an increase in exceptional hydrological events (Joehnk et al., 2004). The effects to the whole lake ecosystem are manifold: Like many other prealpine lakes, the upper section of Lake Constance is largely characterized by a steep trough shape, and a shallow "rim" for the littoral (Type "C," Fig. 10). Extreme droughts would cut of the shallow margins of the lake and strongly affect the biota. In winter, larger areas of exposed sediments freeze, leading to increased mortality of surface-dwellers (e.g., Dreissena mussels), and in summer when water levels are supposed to be highly important habitats for aquatic organisms that depend on the littoral are lost. Considering that large populations of wintering waterbirds depend on these mussels (Werner et al., 2005), and that a large part of the fish community depends on the shallow lake areas (Fischer \& Oehl, 2005), multi-annual low-water phases should lead to tremendous losses in biodiversity and productivity of the whole ecosystem. As a result of the extraordinarily hot summer temperatures at Lake Constance in summer 2003, carp (Cyprinus carpio) yields have skyrocketed. Along with the spread of warm-water adapted organisms, a range of parasites and pathogens that did not previously appear deleterious to the fauna and flora, e.g., fungal diseases in reed, have increased (see contribution by Nechwatal et al., this issue) as well as a large number of fish diseases. The heating-up of the dry part of the ATTZ attracts migrating birds from southern regions and the number of northern migrators is declining (H. G. Bauer, pers. comm.) showing a shift in migrators. Shallow lakes (Type "B", Fig. 10) would periodically cease completely during multi-annual droughts (Mooij et al., 2005; Beklioglu et al., 2007).

Untimely floods, on the other hand, are unlikely to be met by resource-use traits of floodplain species. For example, aquatic invertebrates only slowly colonized the recently flooded ATTZ after a rapid flood in summer 2005 (Wantzen et al., unpublished data). In contrast, terrestrial species that rely on continuous dry conditions are supposed to suffer high mortalities. Notwithstanding, not only the habitat structures become severely altered by irregular floodpulses but also human constructions. For example, recent changes in the hydrological regime have led to an increased erosion of archaeological sites in the littoral of Lake Constance.

Moreover, shallow lakes in central Europe were predicted to suffer a range of negative alterations due to climatic changes, including increased disturbance, reduction of biodiversity, especially of birds and other biota depending on a clear water stage, an increase of cyanobacterial dominance in phytoplankton communities, increased botulism and waterborne diseases, and a benefit invasive species (Mooij et al., 2005). In summary, the functions and importance of the ATTZ and of flood events deserve more attention in conceptual models of climate-related effects on lake ecosystems (Blenckner, 2005; Blenckner et al., 2007).

Based on long-term studies and transplant experiments with macrophytes, Keddy \& Fraser (2000) have established management guidelines for wetlands in large lakes, which recognize the maintenance of the floodpulse as the most important factor in shoreline wetlands.

\section{Conclusions: an extension of the FPC for lakes}

Our analysis has shown that the floodpulse concept applies to lakes, however with some adaptations that 
consider the specific characteristics of lake ecosystems. Due to structural differences between rivers and lakes, floods tend to develop less erosive forces; therefore, less inorganic and organic sediments are mobilized and repositioned in lakes than in rivers. Consequently, flood-mediated landscape patterns such as meandering etc. as found in rivers (e.g., Schumm, 1977) do not occur in lakes; however, their bank structures (erosional/depositional sites) are more strongly influenced by wind forces. Therefore, the habitat diversity in the ATTZ of lakes is supposed to be generally lower than in rivers. Due to the increased residence time in lakes, their floodpulse pattern tends to be less spiky and the drawdown tends to be slower than in rivers. The more depositional characteristics of lake ecosystems facilitates the storage of organic matter in the ATTZ compared to the more dynamic floodplain structure of rivers. The oblong shape of rivers results in their more intensive aquatic-terrestrial interactions than lakes; however, in lakes with a large ATTZ this general pattern can vary. In terms of biodiversity, the corridor shape of river systems increases their resilience to catastrophic flood events and multi-annual drought periods compared with lakes. Hence, the ATTZ acts as a reservoir of resilient species that may recolonize the permanent water body after catastrophic events in both rivers and lakes.

Reformulating the tenets of the Floodpulse Concept (Junk et al., 1989; Junk \& Wantzen, 2004) for lakes, it can be stated that:

- natural floodpulse patterns vary between years and show multi-year phases of drier and wetter years

- the cross-sectional morphology of the basin and the hydrological regime of the catchment are decisive for the spatiotemporal pattern of the flooding and drying

- the floodpulse acts as a strong filter that selects flood-adapted species to colonize the ATTZ, thereby fostering evolutionary processes

- species occurring in the ATTZ are adapted to maximize the use of floodborne resources during their lifecycles ("windows of opportunity") and to minimize losses due to negative effects of floods and droughts on specific lifecycle stages ("phenological windows of susceptibility")

- the timing of the occurrence of a given water level and the period by which an organism can use the floodborne resources or cope with adverse conditions caused by the floodpulse is crucial for the survival of the species in the ATTZ

- the higher the predictability of the floodpulse pattern (including a long-term temporal pattern that allows evolutionary processes) the better the biota are adapted

- due to the increased decomposition and remineralization of nutrients and additional inputs from the catchment or the main water body during the wet-dry cycle, aquatic systems with a pulsing floodplain are more productive than those with a stable water level (floodpulse advantage)

- the interannual variation of the water level allows a sequential use of the ATTZ by different species and thus fosters biodiversity

- the natural intra-annual variation of floodpulses interferes with the species-specific adaptations of the biota and therefore fosters the variable dominances of different species between years

- management schemes for floodplain systems should take advantage from the natural processes triggered by the floodpulse (including increased productivity)

Acknowledgments This paper resulted from presentations and discussions during and after a Workshop on Ecological Effects of Water-level fluctuations in Lakes at the University of Konstanz in December 2005. Avital Gasith (Tel Aviv, Israel), Peter Nõges (Ispra, Italy), Marco Cantonati (Trento, Italy), and Lászlo Tóth (Tihany, Hungary) are acknowledged for valuable contributions. Martin Mörtl and Karsten Rinke, both from University of Konstanz, kindly provided graphs. The workshop was financed by the Sonderforschungsbereich Seenlitoral (SFB 454) of the Deutsche Forschungsgemeinschaft.

\section{References}

Adis, J. \& W. J. Junk, 2002. Terrestrial invertebrates inhabiting lowland river floodplains of Central Amazonia and Central Europe: a review. Freshwater Biology 47: 711-731.

Adis, J., M. I. Marques \& K. M. Wantzen, 2001. First observations on the survival strategies of terricolous arthropods in the northern Pantanal wetland of Brazil-scientific note. Andrias 15: 127-128.

Allan, J. D., 2004. Landscapes and riverscapes: the influence of land use on stream Ecosystems. Annual Review in Ecology Evolution \& Systematics. 35: 257-284.

Amoros, C. \& G. Bornette, 2002. Connectivity and biocomplexity in waterbodies of riverine floodplains. Freshwater Biology 47: 761-776.

Bäuerle, E. \& U. Gaedke (eds), 1999. Lake ConstanceCharacterization of an Ecosystem in Transition. Schweizerbart, Stuttgart. 
Bayley, P. B., 1991. The flood-pulse advantage and the restauration of river-floodplain systems. Regulated Rivers: Research \& Management 6: 75-86.

Beauchamp, D. A., E. R. Byron \& W. Wurtsbaugh, 1994. Summer habitat use by littoral-zone fish in Lake Tahoe and effects on shoreline structures. North American Journal of Fisheries Management 14: 271-280.

Beklioglu, M., G. Altinayar \& C. O. Tan, 2006. Water level control over submerged macrophyte development in five shallow lakes of Mediterranean Turkey. Archiv für Hydrobiologie 166: 535-556.

Beklioglu, M., S. Romo, S. Romo, I. Kagalou, X. Quintana \& E. Becares, 2007. State of the art in the functioning of shallow Mediterranean lakes: workshop conclusions. Hydrobiologia 584: 317-326.

Blenckner, T., 2005. A conceptual model of climate-related effects on lake ecosystems. Hydrobiologia 533: 1-14.

Blenckner, T., R. Adrian, D. M. Livingstone, E. Jennings, G. A. Weyhenmeyer, D. G. George, T. Jankowski, M. Järvinen, C. N. Aonghusa, T. Nõges, D. Straile \& K. Teubner, 2007. Large-scale climatic signatures in lakes across Europe: a meta-analysis. Global Change Biology 13: $1314-1326$

Bohensky, E. L., B. Reyers \& A. S. Van Jaarsveld, 2006. Future ecosystem services in a Southern African river basin: a scenario planning approach to uncertainty. Conservation Biology 20: 1051-1061.

Boon, P. I., P. Virtue \& P. D. Nichols, 1996. Microbial consortia in wetland sediments: a biomarker analysis of the effects of hydrological regime, vegetation and season on benthic microbes. Mar. Freshwater Res. 47: 27-41.

Bornette, G. \& C. Amoros, 1996. Disturbance regimes and vegetation dynamics: role of floods in riverine wetlands. Journal of Vegetation Science 7: 615-622.

Carmouze, J. P., J. R. Durand \& E. Lévêque, 1983. Lake Chad. Ecology and Productivity of a Shallow Tropical Ecosystem. Junk, The Hague, The Netherlands: 575.

Connell, J. H., 1978. Diversity in tropical rain forests and coral reefs. Science 199: 1302-1309.

Coops, H., M. Beklioglu \& T. L. Crisman, 2003. The role of water-level fluctuations in shallow lake ecosystemsworkshop conclusions. Hydrobiologia 506-509: 23-27.

David, P. G., 1994. Wading bird use of Lake Okeechobee relative to fluctuating water levels. Wilson Bulletin 106: 719-732.

Dienst, M., K. Schmieder \& W. Ostendorp, 2004. Effects of water level variations on the dynamics of the reed belts of Lake Constance. Limnologica 34: 29-36.

Dinka, M., E. Agoston-Szabo, A. Bercik \& G. Kutrucz, 2004. Influence of water level fluctuation on the spatial dynamic of the water chemistry at lake Ferto/Neusiedler See. Limnologica 334: 48-56.

Dumont, H. J., 1992. The regulation of plant and animal species and communities in African shallow lakes and wetlands. Revue Hydrobiologie Tropicale 25: 303-346.

Erwin, R. M., 1985. Foraging decisions, patch use, and seasonality in egrets (Aves:Ciconiiformes). Ecology 63: 837-844.

Euliss, N. H. Jr., R. A. Gleason, A. Olness, R. L. McDougal, H. R. Murkin, R. D. Robarts, R. A. Bourbonniere \& B. G. Warner, 2006. North American prairie wetlands are important nonforested land-based carbon storage sites. Science of the Total Environment 361: 179-188.

Evans, M. \& Y. Mohieldeen, 2002. Environmental change and livelihood strategies: the case of Lake Chad. Geography 87(1): 3-13.

Fischer, P. \& U. Oehl, 2005. Effects of water-level fluctuations on the littoral benthic fish community in lakes: a mesocosm experiment. Behavioral Ecology 16: 741-746.

Forbes, S. A., 1887. The Lake as a Microcosm. Bulletin of the Scientific Association, Peoria, IL: 77-87.

Gafny, S. \& A. Gasith, 1999. Spatially and temporally sporadic appearance of macrophytes in the littoral zone of Lake Kinneret, Israel: taking advantage of a window of opportunity. Aquatic Botany 62: 249-267.

Gafny, S., A. Gasith \& M. Goren, 1992. Effect of water level fluctuation on shore spawning of Mirogrex terraesanctae (Steinitz), (Cyprinidae) in Lake Kineret, Israel. Journal of Fish Biology 41: 863-871.

Gasith, A. \& S. Gafny, 1998. Importance of Physical Structures in Lakes: The Case of Lake Kinneret and General Implications. In Jeppesen, E., M. A. Sondergaard, M. Sondergaard \& K. Christoffersen (eds), The Structuring Role of Submerged Macrophytes in Lakes. Springer Verlag, Berlin: 331-338.

Gasith, A., S. Gafny \& M. Goren, 2000. Response of the fish assemblage of rocky habitats to lake level fluctuations: possible effect of varying habitat choice. Archiv für Hydrobiolie Special Issues Adances in Limnology 55: 317-331.

Geraldes, A. M. \& M. J. L. Boavida, 2004. Limnological variations of a reservoir during two successive years: one wet, another dry. Lakes and Reservoirs: Research and Management 9: 143-152.

Grossart, H.-P. \& M. Simon, 1998. Bacterial colonization and microbial decomposition of limnetic organic aggregates (lake snow). Aquatic Microbial Ecology 15: 127-140.

Güde, H., P. Teiber, S. Rolinski \& M. M. Sala, 2004. Comparison of production and degradation of organic matter at a littoral site of the prealpine Lake Constance. Limnologica 34: 117-123.

Gurnell, A. M., P. G. Angold \& I. P. Morissey, 2003. Evidence for hydrochory and the deposition of viable seeds within winter flow-deposited sediments: the River Dove, Derbyshire, UK. River Research \& Applications 19: 317-334.

Gurnell, A. M., G. E. Petts, D. M. Hannah, B. P. G. Smith, P. J. Edwards, J. Kollmann, J. V. Ward \& K. Tockner, 2001. Riparian vegetation and island formation along the gravelbed Fiume Tagliamento, Italy. Earth Surface Processes and Landforms 26: 31-62.

Humphries, P. \& P. S. Lake, 2003. Fish recruitment on floodplains: the roles of patterns of flooding and life history characteristics. Canadian Journal of Fisheries \& Aquatic Sciences 60: 773-786.

IPCC, 2001. Climate Change 2001: Synthesis Report, Intergovernmental Panel on Climate Change (IPCC), Geneva, Switzerland, 184 pp.

Joehnk, K. D., D. Straile \& W. Ostendorp, 2004. Water level variability and trends in Lake Constance in the light of the 1999 centennial flood. Limnologica 34: 15-21.

Junk, W. J., 1985. Temporary fat storage, an adaptation of some fish species to the waterlevel fluctuations and related 
environmental changes of the Amazon river. Amazoniana 9: 315-351.

Junk, W. J., P. B. Bayley \& R. E. Sparks, 1989. The flood pulse concept in river-floodplain systems. Special Publication of the Canadian Journal of Fisheries and Aquatic Sciences 106: $110-127$.

Junk, W. J. \& K. M. Wantzen, 2004. The Flood Pulse Concept: New Aspects, Approaches, and Applications-An Update. In Welcomme, R. \& T. Petr (eds), Proceedings of the 2nd Large River Symposium (LARS), Pnom Penh, Cambodia [Food and Agriculture Organization \& Mekong River Commission. FAO Regional Office for Asia and the Pacific, Bangkok. RAP Publication 2004/16]: 117-149.

Junk, W. J. \& K. M. Wantzen, 2006. Flood Pulsing, and the Development and Maintenance of Biodiversity in Floodplains. In Batzer, D. P. \& R. R. Sharitz (eds), Ecology of Freshwater and Estuarine Wetlands. University of California Press, Berkeley: 407-435.

Junk, W. J., K. M. Wantzen, C. Nunes da Cunha, P. Petermann, C. Strüssmann, M. Marques \& J. Adis, 2006. Comparative biodiversity value of large wetlands: the Pantanal of Mato Grosso, Brazil. Aquatic Sciences 63: 278-309.

Keddy, P. \& L. H. Fraser, 2000. Four general principles for the management and conservation of wetlands in large lakes: the role of water levels, nutrients, competitive hierarchies and centrifugal organization. Lakes and Reservoirs: Research and Management 5: 177-185.

Keogh, T. M., P. A. Keddy \& L. H. Fraser, 1999. Patterns of tree species richness in forested wetlands. Wetlands 19: 639-647.

Kless, U., 2003. Faunistisch-ökologische Untersuchungen an Culiciden des westlichen Bodenseegebiets unter besonderer Berücksichtigung von Aedes vexans (MEIGEN, 1830) (Diptera, Nematocera). $\mathrm{PhD}$ thesis. Universität Konstanz, Germany.

Kreuzwieser, J., E. Papadopoulou \& H. Rennenberg, 2004. Interaction of flooding with carbon metabolism of forest trees. Plant Biology (Stuttgart) 6: 299-306.

Kufel, L. \& I. Kufel, 2002. Chara beds acting as nutrient sinks in shallow lakes: a review. Aquatic Botany 72: 249-260.

Lae, R., 1994. Effects of drought, dams, and fishing pressure on the fisheries of the central delta of the Niger River. International Journal of Ecology and Environmental Sciences 20: 119-128.

Larmola, T., J. Alm, S. Juutinen \& S. Saarnio, 2004. Floods can cause large interannual differences in littoral net ecosystem productivity. Limnology and Oceanography 49: 1896-1906

Lim, P., S. Lek, S. T. Touch, S. O. Mao \& B. Chbouk, 1999. Diversity and spatial distribution of freshwater fish in Great Lake and Tonle Sap river (Cambodia, Southeast Asia). Aquatic Living Resources 12: 379-386.

Löffler, H., 1997. Neusiedler See: The Limnology of a Shallow Lake in Central Europe. Dr. W. Junk Publisher, The Hague-Boston-London: 543.

Manring, S. L. \& S. Pearsall, 2005. Creating an adaptive ecosystem management network among stakeholders of the lower Roanoke River, North Carolina, USA. Ecology \& Society 10(2):16. http://www.ecologyandsociety.org/vol10/iss2/ $\operatorname{art} 16 /$.
Marchese, M. R., K. M. Wantzen \& I. Ezcurra de Drago, 2005. Benthic invertebrate assemblages and species diversity patterns of the Upper Paraguay River. River Research and Applications 21: 1-15.

McClain, M. E., E. W. Boyer, C. L. Dent, S. E. Gergel, N. B. Grimm, P. Groffman, S. C. Hart, J. Harvey, C. Johnston, E. Mayorga, W. H. McDowell \& G. Pinay, 2003. Biogeochemical hot spots and hot moments at the interface of terrestrial and aquatic ecosystems. Ecosystems 6: 301-312.

Monheim, F., 1956. Beiträge zur Klimatologie und Hydrologie des Titicacabeckens. Heidelberger Geographische Arbeiten (Geographisches Institut der Universität Heidelberg) 1: $1-152$.

Mooij, W. M., L. N. De Senerpont Domis, B. A. Nolet, P. L. E. Bodelier, P. C. M. Boers, L. M. D. Pires, H. J. Gons, B. W. Ibelings, R. Noordhuis, R. Portielje, K. Wolfstein \& E. H. R. R. Lammens, 2005. The impact of climate change on lakes in the Netherlands: a review. Aquatic Ecology 39: 381 .

Nickel, A., D. Hahn, K. Zepp \& J. Zeyer, 1999. In situ analysis of introduced Frankia populations in root nodules of Alnus glutinosa grown under different water availability. Canadian Journal of Botany 77: 1231-1238.

Nogueira, F., E. G. Couto \& C. J. Bernardi, 2002. Geostatistics as a tool to improve sampling and statistical analysis in wetlands: a case study on dynamics of organic matter distribution in the Pantanal of Mato Grosso, Brazil. Brazilian Journal of Biology 62: 861-870.

Nunes da Cunha, C. \& W. J. Junk, 2001. Distribution of woody plant communities along the flood gradient in the Pantanal of Poconé, Mato Grosso, Brazil. International Journal of Ecology and Environmental Sciences 27: 63-70.

Paetzold, A., C. Schubert \& K. Tockner, 2005. Aquaticterrestrial linkages along a braided river: riparian arthropods feeding on aquatic insects. Ecosystems 8: 748-759.

Parolin, P., O. De Simone, K. Haase, D. Waldhoff, S. Rottenberger, U. Kuhn, J. Kesselmeier, B. Kleiss, W. Schmidt, M. T. F. Piedade \& W. J. Junk, 2004. Central Amazonian floodplain forests: tree adaptions in a pulsing system. The Botanical Review 70: 357-380.

Pawley, A., S. C. Fritz, P. A. Baker, G. O. Seltzer \& R. Dunbar, 2001. The Biological, Chemical, and Physical Limnology of Lake Titicaca, Bolivia/Peru. In Munawar, M. \& R. E. Hecky (eds), The Great Lakes of the World (GLOW): Food-web, Health and Integrity. Backhuys Publishers, Leiden, The Netherlands: 195-215.

Peintinger, M., D. Prati \& E. Winkler, 2007. Water-level fluctuations and dynamics of amphibious plants at Lake Constance: long-term study and simulation. Perspectives in Plant Ecology Evolution and Systematics 8: 179-196.

Poole, G. C., 2002. Fluvial landscape ecology: addressing uniqueness within the river discontinuum. Freshwater Biology 47: 641-660.

Puckridge, J. T., F. Sheldon, K. F. Walker \& A. J. Boulton, 1998. Flow variability and the ecology of large rivers. Marine and Freshwater Research 49: 55-72.

Ramberg, L., P. Hancock, M. Lindholm, T. Meyer, S. Ringrose, J. Sliva, J. Van As \& C. Vander Post, 2006. Species diversity of the Okavango Delta, Botswana. Aquatic sciences 68: 310-337. 
Roche, M. A., J. Bourges, J. Cortes \& R. Mattos, 1992. Climatology and Hydrology of Lake Titicaca Basin. In Dejoux, C. \& A. Iltis (eds), Lake Titicaca-A Synthesis of Limnological Knowledge. Kluwer Academic Publishers, Dordrecht: $63-88$.

Sala, M. M. \& H. Güde, 2006. Seasonal dynamics of pelagic and benthic (littoral and profundal) bacterial abundances and activities in a deep prealpine lake (L. Constance). Archiv Fuer Hydrobiologie 167: 351-369.

Scheffer, M., 2004. Ecology of Shallow Lakes. Kluwer Academic Publishers, Dordrecht, The Netherlands: 357.

Scheffer, M. \& E. Jeppesen, 1998. Alternative Stable States. In Jeppeson, E., M. Sondergaard, M. Sondergaard \& K. Christoffersen (eds), Ecological Studies 131. The Structuring Role of Submerged Macrophytes in Lakes. Fischer, New York: 397-406.

Schiemer, F., C. Baumgartner \& K. Tockner, 1999. Restoration of floodplain rivers: the 'Danube restoration project'. Regulated Rivers-Research \& Management 15: 231-244.

Schmieder, K., M. Dienst, W. Ostendorp \& K. Joehnk, 2004. Effects of water level variations on the dynamics of the reed belts of Lake Constance. Ecohydrology and Hydrobiology 4: 469-480.

Schulz, M., 2007. Morphodynamics at the shore of Mehrerau (Lake Constance). Limnologica 34: 75-82.

Schumm, S. A., 1977. The Fluvial System. Springer, New York: 388.

Sobek, S., L. J. Tranvik, Y. T. Prairie, P. Kortelainen \& J. J. Cole, 2007. Patterns and regulation of dissolved organic carbon: an analysis of 7,500 widely distributed lakes. Limnology and Oceanography 52: 1208-1219.

Sparks, R. E., J. C. Nelson \& Y. Yin, 1998. Naturalization of the flood regime in regulated rivers. BioScience 48: 706-720.

Straile, D., R. Eckmann, T. Juengling, G. Thomas \& H. Loeffler, 2007. Influence of climate variability on whitefish (Coregonus lavaretus) year-class strength in a deep, warm monomictic lake. Oecologia 151: 521-529.

Strand, M., 2005. Trophic ecology of the Lake Superior wave zone: a stable isotope approach. Hydrobiologia 544: 271-278.

Thomaz, S. M., L. M. Bini \& R. L. Bozelli, 2007. Floods increase similarity among aquatic habitats in river-floodplain systems. Hydrobiologia 579: 1-13.

Thompson, J. R., 1996. Africa's Floodplains: A Hydrological Overview. In Acreman, M. C. \& G. F. Hollis (eds), Water Management and Wetlands Conservation in Sub-saharan Africa IUCN-The World. Conservation Union, Gland, Switzerland: 5-20.

Tockner, K. \& J. V. Ward, 1999. Biodiversity along riparian corridors. Archiv fur Hydrobiologie 115: 293-310.

Tockner, K., F. Malard \& J. V. Ward, 2000. An extension of the flood pulse concept. Hydrological Processes 14: 28612883.

Villwock, W., 1993. Die Titicaca-See-Region auf dem Altiplano yon Peru und Bolivien und die Folgen eingeführter Fische für Wildarten und ihren Lebensraum. Naturwissenschaften 80: 1-8.

Waldhoff, D., B. Furch \& W. J. Junk, 2002. Fluorescence parameters, chlorophyll concentration, and anatomical features as indicators for flood adaption of an abundant tree species in Central Amazonia: Symmeria paniculata. Environmental and Experimental Botany 48: 225-235.
Waldhoff, D. \& W. J. Junk, 1998. Responses of three Central Amazonian tree species to drought and flooding under controlled conditions. International Journal of Ecology and Environmental Sciences 24: 237-252.

Wantzen, K. M., E. Drago \& C. J. da Silva, 2005a. Aquatic habitats of the Upper Paraguay River-Floodplain-System and parts of the Pantanal (Brazil). Ecohydrology \& Hydrobiology 21: 1-15.

Wantzen, K. M. \& W. J. Junk, 2006. Aquatic-terrestrial linkages from streams to rivers: biotic hot spots and hot moments. Archiv für Hydrobiologie Supplements 158: 595-611.

Wantzen, K. M., M. Korn, J. Pucher \& K.-O. Rothaupt, 2005 b. Einfluß des Flutpulses auf aquatische Invertebraten im eulitoralen Interstitial des Bodensees. Bundesamt für Naturschutz Bonn. Treffpunkt Biologische Vielfalt VI: 205-213.

Wantzen, K. M., F. A. Machado, M. Voss, H. Boriss \& W. J. Junk, 2002. Floodpulse-induced isotopic changes in fish of the Pantanal wetland, Brazil. Aquatic Sciences. 64: 251.

Ward, J. V., 1998. Riverine landscapes: biodiversity patterns, disturbance regimes and aquatic conservation. Biological Conservation 83: 269-278.

Ward, J. V. \& K. Tockner, 2001. Biodiversity: towards a unifying theme for river ecology. FreshwatBiol 46: 807-819.

Ward, J. V., K. Tockner, D. B. Arscott \& C. Claret, 2002. Riverine landscape diversity. FreshwatBiol 47: 517-539.

Ward, J. V., K. Tockner \& F. Schiemer, 1999. Biodiversity of floodplain river ecosystems: ecotones and connectivity. Regulated Rivers-Research \& Management 15: 125-139.

Welcomme, R. L., 1979. Fisheries Ecology of Floodplain Rivers. Longman, London: 317.

Welcomme, R. \& A. Halls, 2001. Some considerations of the effects of differences in flood patterns on fish populations. Ecohydrology \& Hydrobiology 1: 313-321.

Werner, S., M. Moertl, H. G. Bauer \& K. H. Rothhaupt, 2005. Strong impact of wintering waterbirds on zebra mussel (Dreissena polymorpha) populations at Lake Constance, Germany. FreshwatBiol 50: 1412-1426.

Wetzel, R. G., 2001. Limnology: Lake and River Ecosystems. Academic Press, San Diego: 1005.

Wisheu, I. C. \& P. Keddy, 1992. Competition and centrifugal organization of plant communities: theory and tests. Journal of Vegetation Science 3: 147-156.

Witthöft-Mühlmann, A., K. O. Rothhaupt \& W. Traunspurger, 2002. Meiobenthische Lebensgemeinschaften im Flussmündungsgebiet der Schussen, Bodensee. Ansätze zur Anwendung der "Intermediate Disturbance Hypothesis". DGL Tagungsbericht 2001 (Kiel) Band I: 515-520.

Wittmann, F., W. J. Junk \& M. T. F. Piedade, 2004. The varzea forests in Amazonia: flooding and the highly dynamic geomorphology interact with natural forest succession. Forest Ecology \& Management. 196: 199-212.

Ybert, J.-P., 1992. Ancient Lake Environments (Deduced from Pollen Analysis). In Dejoux, C. \& A. Iltis (eds), Lake Titicaca-A synthesis of Limnological knowledge. Kluwer Academic Publishers, Dordrecht, The Netherlands: 49-61.

Zerm, M. \& J. Adis, 2000. On the life cycles of Phaeoxantha species (Coleoptera: Cicindelidae) from central Amazonian floodplains (Brazil). Ecotropica 6: 141-155. 